This is the accepted manuscript of the article, which has been published in

Scandinavian Journal of Public Health. 2019, 47(6), 611-617.

https://doi.org/10.1177/1403494818780024

\title{
Ageing populations in the Nordic countries: mortality and longevity from 1990-2014
}

Terese Sara Høj Jørgensen ${ }^{1}$, Stefan Fors², Charlotte Juul Nilsson¹, Linda Enroth ${ }^{3}$, Mari Aaltonen ${ }^{3,4}$, Louise Sundberg ${ }^{2}$, Henrik Brønnum-Hansen¹, Bjørn Heine Strand ${ }^{5}$, Milan Chang ${ }^{6,7,8}$, Marja Jylhä ${ }^{3}$

1. Section of Social Medicine, Department of Public Health, Faculty of Health and Medical Sciences, University of Copenhagen, Denmark. Address: Øster Farimagsgade 5, 1014 Copenhagen K, Denmark

2. Aging Research Center, Department of Neurobiology, Care Sciences and Society, Karolinska Institutet and Stockholm University, Sweden. Address: Gävlegatan 16, 11330 Stockholm, Sweden.

3. Faculty of Social Sciences and Gerontology Research Center (GEREC), University of Tampere, Finland. Address: University of Tampere, Arvo-building, Arvo Ylpön katu 34, 33520 Tampere, Finland.

4. Institute for Advanced Social Research, University of Tampere, Finland. Address: Ratapihankatu 55, 2nd and 3rd floor, 33014 University of Tampere, Finland

5. Department on Ageing, Norwegian Institute of Public Health. Address: Marcus Thranes gt 6, 0473 Oslo, Norway

6. The Icelandic Gerontological Research Center, Landspitali University Hospital \& University of Iceland, Reykjavik, Iceland. Address: Landakot K-5, Tungata, Reykjavik 101, Iceland

7. Physical Activity, Physical Education, Health and Sport (PAPESH) Research Centre, Sport Science, School of Science and Engineering, Reykjavik University, Reykjavik, Iceland. Address: Mentavegi 1, Reykjavik 101, Iceland

8. Faculty of Sport, Leisure Studies and Social Education, School of Education. University of Iceland, Stakkahlíð, 105 Reykjavík, Iceland

Word count: main text 3238 words; abstract 247 words.

References: 24

\section{Corresponding author:}

Terese Sara Høj Jørgensen

Section of Social Medicine, Department of Public Health, University of Copenhagen

Øster Farimagsgade 5, Postboks 2099, 1014 Copenhagen K, Denmark

E-mail: Tshj@sund.ku.dk and Phone: +45 22483748

ORCID: 0000-0003-1450-4472 


\section{ABSTRACT:}

Aims: Cross-country comparisons of the Nordic populations' mortality and longevity patterns could contribute with novel insight into the compositional changes of the Nordic populations. We investigated three metrics on population ageing; the proportion of the populations aged $75+$ and $90+$ years, the proportion of birth cohorts reaching 75 and 90 years, and life expectancy (LE) at age 75 and 90 years in Sweden, Norway, Iceland, Denmark and Finland, in the period 1990-2014.

Methods: Demographic information was collected from national statistical databases and the Human Mortality Database.

Results: All metrics on population ageing increased during the study period, but there were some cross-country variations. Finland experienced a noteworthy steep increase in the proportion of $75+$ and $90+$ year olds compared to the other countries. Regarding the proportion reaching old ages, the Finnish lagged behind from the beginning, but the females decreased the differences. The Danes were more similar to the other countries at the beginning, but did not experience the same increase over time. Gender-specific LE at age 75 and 90 years were overall similar in the five countries.

Conclusions: The developments in cross-country variation suggest that survival until old age have become more similar for Finnish females and more different for Danish males and females compared with the other countries in the last decades. This provides perspectives on the potentials to improve longevity in Denmark and Finland. Similarities in LE in old age suggest that expected mortality in old age has been more similar throughout the period.

Key words: Demographics, Ageing populations, Life expectancy, Nordic countries 


\section{INTRODUCTION}

Many countries face ageing populations (1). In high-income countries, this is mainly due to low fertility, low immigration, and increasing longevity (i.e., the length of the average life span in the population) (2). During the $20^{\text {th }}$ century, life expectancy (LE) increased remarkably due to a shift in the main causes of death from infections, leading to high infant and child mortality, to non-communicable diseases that mainly occur later in life (3). Today, LE in old age is increasing much faster in high-income countries compared to low and middle-income countries, however great variation between countries and genders remains (1).

Knowledge about demographic changes is important for policymaking as it illustrates the age and gender distribution of a country's population and reflects the fertility and longevity. In the Nordic countries (Sweden, Norway, Iceland, Denmark and Finland), the ageing of the populations pose a great challenge for the traditional social welfare state, due to the increasing old-age dependency ratio and the pressure it puts on the health and long-term care systems (2).

The Nordic countries are known for their similarities, shaped by a shared history, which has led to common traditions and norms. They also have comparable climate and political systems, characterized by welfare states with universal healthcare systems (4). Yet, there are differences between the countries, for example in terms of general public health policies and the organization of care work for older people $(5,6)$. Social policies in the Nordic countries support longevity, economic security, and limit social exclusion among the older segment of the populations $(7,8)$.

Detailed cross-country comparisons could contribute with novel insights into the conditions and mechanisms that have generated potential differences in the longevity, and the composition of the older segment of the populations. Given the similarities between the countries, such comparisons could provide important information about the potential to improve longevity also in old age. Thus, the overarching aim of the study is to investigate the dynamics of population ageing in the Nordic countries. We will do this by analyzing the development of three metrics of population ageing for each of the five Nordic countries, during the period 1990-2014: 1) the proportion of people aged 75+ and 90+ years, 2) the proportion of birth cohorts reaching age 75 and 90 years, and 3) the LE at age 75 and 90 years. These aims cover three related aspects of population ageing over the last 25 years. The proportion of older people provides information about the age structure of the Nordic populations. The proportion of birth cohorts that reach old age provides information on the real life longevity of the cohorts that reached old age during the study period. LE in old age provides a summary measure of the mortality in the old age population during the study period. The two latter (proportion that reach old age and LE in old age) furthermore contribute to the explanation of the development of the proportion of older people in the Nordic countries 
during the study period. The specific ages 75 and 90 years were selected as these represent the ages for which elderly care services are planned $(75+$ years $)$ and the rapidly emerging oldest old group $(90+$ years).

\section{DATA AND METHODS}

Information about the age and gender distributions of the populations in Sweden, Norway, Iceland, Denmark, and Finland during the period 1990-2014 were collected from the countries' national statistical databases (http://dst.dk/, http://www.scb.se/, http://www.ssb.no/, http://www.statice.is/, http://www.stat.fi/). Data on LE were collected from period life tables for the period 1990-2012, and the proportions of males and females that reached 75 and 90 years in the cohorts born between 1900 and 1921 (Age 75 years in 1975-1996 and age 90 years in 1990-2011) were collected from cohort life tables, available from the Human Mortality Database (http://www.mortality.org/). The cohort life tables show the birth cohort specific probabilities of death each year. The calculation is exact when there is no migration, but it is also reasonably approximate in most situations where the direction and magnitude of migration are the same for those who die and those who stay alive (9). Decomposition technique was used to estimate the contribution of change in mortality of different age groups to the total differences in LE at age 75 years between 1990 and 2012 (10). The age decomposition is the sum of the direct, indirect and interaction effect. The direct effect is the number of years an age group adds to LE due to change in mortality rates between $\mathrm{x}$ and $\mathrm{x}+\mathrm{n}$. The indirect and interaction effects are the years added from those extra survivors between $\mathrm{x}$ and $\mathrm{x}+\mathrm{n}$ when they meet new mortality conditions (11).

\section{RESULTS}

\section{Proportions of people aged $75+$ and $90+$ years}

From 1990 to 2014, all the Nordic countries experienced an increase in the numbers of males and females aged 75+ and $90+$ years (Table 1 and Figure 1). Sweden had the greatest proportion of males aged $75+$ and $90+$, and females aged $75+$ (until 2008) and 90+ years throughout the study period. Iceland had the lowest proportion of males and females aged $75+$, and females aged $90+$ years throughout the study period. In 1990, Iceland had the same proportion of males aged 90+ years old as the other countries, but was the country with the lowest proportion in 2014.

All countries experienced increases in the proportion of $90+$ year olds, while the pattern for the $75+$ year olds differed between the countries (Fig 1 and appendix Tab A1). The proportions of females aged $75+$ years increased during the whole period in Finland and Iceland, whereas the proportions were stable, or even decreased, the last decade in Sweden, 
Denmark and Norway. Furthermore, Finland had noteworthy steep increases in the proportions of males and females aged $75+$ and $90+$ years during the period.

\section{Proportion reaching 75 and 90 years}

There were great differences in the proportion reaching old age between the Nordic countries (Figure 2 and appendix Table A2 for the corresponding numbers). In the most recent birth cohort, the probability for males reaching age 75 years was highest in Iceland (52\%) and lowest in Finland (30\%). For females, this probability was highest in Norway (68\%) and lowest in Finland (57\%). Sweden had the highest proportion of males (12\%) and females (25\%) that reached 90 years, whereas the proportions were again markedly lower among Finnish males (6\%), and Finnish females (20\%) as well as for Danish males (8\%) and females (19\%).

The proportion of birth cohorts reaching old age increased in the more recent born birth cohorts in all countries, but at a slower pace in Denmark. Finnish females in the earliest cohorts were lagging behind the other counties, but the most recent birth cohorts caught up with Danish females. All birth cohorts of Finnish males kept lagging behind the other countries.

\section{Life expectancy at the ages of 75 and 90 years}

LE at age 75 and 90 years for both males and females increased at similar pace in all countries during the study period, except for Icelandic males aged 90 years; who experienced a reduction in LE. Males and females in Finland and Denmark had the lowest LE throughout the period, although these differences were minor (Figure 3 and appendix Table A3 for the corresponding numbers.). Icelandic males and females had the lowest absolute increase in LE at age 75 and 90 years (males: 75:1.8 years, 90:-0.3 years and females: 75:1.0 years, 90:0.3 years). Finnish males had the largest increase at age 75 (2.6 years) and 90 (0.4 years) years and Finnish females had the largest increase at age 75 years (2.7 years), whereas Danish females had the largest increase at age 90 years $(0.7$ years).

The increases in male LE at age 75 years from 1990 to 2012 were mostly driven by decreasing mortality in the youngest age group (75-79 year) (Table 2). For females, decreasing mortality in the two youngest age groups (75-79 and 80-84 years) contributed equally to the increase in LE. The increase in LE at age 75 years among the Icelandic females and 
males were to a higher degree than for those in the other countries driven by decreasing mortality in the age group 75-79 years, especially for females.

\section{DISCUSSION}

All the Nordic populations experienced increases in the proportion of older people during the last decades. During the same period, the proportion of consecutive birth cohorts reaching old ages and LE at old ages increased. Cross-country variations were especially prominent in terms of the proportions of birth cohorts that reached old age.

\section{Country similarities and differences in mortality}

Low fertility, low immigration, and longevity are the main drivers behind the increases in the proportion of older adults in populations of high-income countries (2). Thus, these three factors may also explain the increases and differences in the proportion of older adults in the Nordic countries.

While the baby boom peaked during the Second World War (WW2) in Sweden, Norway and Denmark, it did not peak until the end of WW2 in Finland, and shortly after WW2 in Iceland (12). This may have contributed to the lower proportion of males and females aged $75+$ years in Iceland compared to the other countries during the study period. A study of fertility patterns in Sweden, Denmark and Finland has shown overall similar trends in total fertility rates from 1960 to 2005; fertility rates declined in all the countries and reached historical low rates in early 1970s in Finland and in mid-1980s in the other countries (13). Thus, low fertility rates may contribute to the general increase in the proportion of older adults, but not to the variation between the countries. The stable development in the proportion of females and males in Norway and Sweden may be explained by greater decline in the sizes of the birth cohorts from 1915 (75 years in 1990) to 1939 ( 75 years in 2014). Based on numbers from the Human Mortality database, the sizes of the 1939 birth cohorts were $20.8 \%$ and $20.5 \%$ smaller for Swedish and Norwegian females and $20.9 \%$ and $21.5 \%$ smaller for Swedish and Norwegian males compared to the 1915 birth cohorts. In Iceland, Finland and Denmark, the sizes of the 1939 birth cohorts were only $4.1-5.4 \%$ smaller for females and 1.4-6.9\% smaller for males compared to the 1915 birth cohorts.

In 1990, Sweden had by far the highest inflow of immigrants $(\mathrm{N}=53,200)$ followed by lower levels in Norway $(\mathrm{N}=15,696)$ and Denmark ( $\mathrm{N}=15,051)$ and markedly lower levels in Finland $(\mathrm{N}=6492)$ (Iceland not included in the OECD statistics). From 1990 to 2014, the inflow of immigrants increased in all the countries with the highest absolute increase in numbers to Sweden by an inflow of 52,900 (99.4\%) immigrants. Norway and Denmark experienced similar increases in inflow of 
immigrants by increases of 45,733 (278.6\%) immigrants to Norway and 33,988 (225.8\%) immigrants to Denmark. Finland by far had the lowest absolute increase in inflow of immigrants by an increase of 17,155 (264.2\%) immigrants (14). This could indicate that low immigration does not explain the increase in the proportion of older people in the Nordic countries, yet additional analyses are needed to identify the specific influence of immigration patterns.

The ageing of the populations in all countries is partly attributable to improved survival to old age in more recent birth cohorts. This may have a number of explanations. In the past 50 years, the Nordic countries have experienced a development into modern welfare states (15), which contribute to increased longevity. A study by Vollset (2013) elucidates changes in causes of death in the age group 40-70 years in the period 1951-2010 in the Nordic countries, which may explain some of the cross-county variation found in our study. Vollset showed that since the 1970s for men and since the 1950s for females, there has been a notable decrease in middle-age death risk, mainly driven by decreases in deaths from circulatory diseases (15). In line with our findings, Vollset reports that initially Finnish males and females had the highest middle-age death risk among the Nordic countries, and Finnish males continued having the overall highest death risk until they caught up with Denmark in the 1990s. Finnish females had the highest death risk until mid-1970s when they reached the same level as the other Nordic countries and was surpassed by Danish females (15). The death risk for Danish females increased from late 1970s to mid-1990s, hereafter it decreased sharply. Furthermore, death risk from cancer increased both among Danish males and females in the period between 1950 and 1990 - a period where the other four countries experienced decreases (15). Another Nordic study has implied that higher mortality from cancer in this period among Danes could be explained by late diagnostics (16). Differences in health-related behaviours between the countries could also explain some of the differences in mortality. Using OECD data, Vollset (2013) shows that alcohol consumption generally increased in all of the countries between 1960 and 2005, with the exception of Iceland where alcohol consumption had decreased since 1975. On the other hand, the proportions of smokers for both genders decreased in all countries in the period 1970-2005. Denmark had the highest alcohol consumption during the period 1960-2010, and the highest proportion of smokers during the period 1970-1990 (15). Also, the smoking prevalence was higher among all Danish female birth cohorts born between 1900 and 1950 compared to those in Sweden and Norway (17). The lower proportion of Finns that reached old age may partly be explained by the high number of deaths during the Civil War in $1918(\mathrm{n}=36,640)(18)$ and the WW2 in 1939-1945 $(\mathrm{n}=93,017)(19)$ and the related consequences on the subsequent living conditions. Altogether, worse health related behaviour and cancer survival in Denmark, and the war consequences in Finland, could explain high mortality in midlife in the birth cohorts that reached old age during the study period, and consequently also to a lower proportion of older people. 
LE in old age was similar across the countries and increased at a comparable pace during the period 1990-2012. Danish and Finnish males and females had the lowest LE at age 75 years, but the differences were minor.. A possible explanation of the similarities in LE at old age between the countries is that living conditions and health-related behaviours in old age have been more similar throughout the study period or/and that these factors are of less importance for mortality in old age. However, the countries differed in regard to which age groups that contributed most to gain in LE from 1990 to 2014 ; the relative impact of the age group 75-79 years was much higher in Iceland compared to the other countries. This is likely to be a consequence of the higher survival in very old age in Iceland in the beginning of the period. Given the other Nordic countries had higher mortality in the age groups $80+$ years, similar absolute improvement in survival have led to greater relative improvements in these oldest age groups in the four other countries compared to Iceland.

\section{Gender differences}

Throughout the study period, the proportions of people in old ages, the proportions of birth cohorts that reached old ages, and LE at old ages were greater among females than males in all countries. A study by Beltrán-Sánchez et al. (2015) of the 1800-1935 birth cohorts in 13 developed countries including Sweden, Norway and Denmark, showed that the female survival advantage emerged for cohorts born after 1880 . The gender differences in mortality were mostly concentrated to the age groups 50-70 years and almost disappeared at age 90 years. The gender differences were mainly driven by a greater vulnerability towards cardiovascular diseases among males and smoking was estimated to account for $30 \%$ of the excess male mortality (20). During our study period, we found that the gender differences in the proportions of males and females aged 75 years and older in the population decreased in all the countries, and mostly so in Finland. In Finland this is possibly due to the converging gender patterns of alcohol consumption and alcohol related deaths(21, 22). and that the high number of deaths during the Civil War in 1918 (18) and WW2 (19) led to high male mortality in the first part of the period.

Males experienced a greater increase in LE at age 75 than women between 1990 and 2012, in all the countries except Finland. The increases in male LE were mainly driven by decreasing mortality in a narrower age group (75-79 years) than the increases in female LE (75-84 years). This may be a result of males' greater potential for improving survival at younger ages due to their greater mortality in the beginning of the period. The observed decreases in the gender gap in LE at age 75 in our study are in line with results from a study of the development in gender gap in LE at age 65 years in 17 countries (including Denmark, Norway, Sweden and Finland) in the period 1751-2007. . The study identified three phases of 
development that most of the countries went through: A) less than one year advantage in LE among females and a generally short life span, B) increase in female advantage in LE, and C) the gender gap in LE stopped to increase and started to decrease. The timing of the phases differed between the countries, but the third phase $\mathrm{C}$ characterized by a decrease in the gender gap in LE, led up to the first half of our study period (23). The gender differences in LE in 53 countries in the period 1955-2009 have been shown to be explained by smoking, biological factors (defined by the authors as "natural basis of gender-difference in LE") and other non-biological factors (the part not explained by smoking and biological factors). According to the study, both the magnitude of, and change in, the gender gap in LE in Finland could be attributed to smoking patterns. In Iceland and Sweden, other non-biological factors predominantly drove the magnitude and trend of the gender gap. In Denmark and Norway, other non-biological factors primarily drove the size of the gender gap, but smoking drove the trend. In all the countries, the impact of smoking decreased during the period (24).

\section{Policy implications}

The observed low proportion of Danish and Finnish birth cohorts that reached old age emphasize the need for Danish and Finnish policymakers to identify and intervene on factors that may have led to this unfavorable development (e.g. policies on alcohol consumption and smoking and quality of healthcare services). Notably, despite the differences in the likelihood of reaching old age, LE at old age did not differ markedly between the countries. Thus, policymakers can note that it does not seem to be on the expense of the general health of the older populations that a larger proportion of Swedes, Norwegians and Icelanders reach old age compared to Danes and Finns.

\section{CONCLUSION}

During the last decades, all the Nordic populations have experienced an increase in the segments of people in old ages. At the same time, the proportion of consecutive birth cohorts reaching old ages and LE at old ages have increased. However, there were some cross-country variations between the Nordic countries, especially in terms of the proportions of birth cohorts that reached old age. The Finnish males and females initially lagged behind the other countries, but Finnish females became more similar to the other countries during the study period, whereas Finnish males kept lacking behind. On the other hand, Danish males and females started out similarly to the other countries, but then had a more unfavourable development, where those in the most recent birth cohorts had a lower likelihood of reaching old age than those in the corresponding cohorts in the other countries. 
Acknowledgement: We would like to thank Statistics Sweden, Statistics Finland, Statistics Denmark, Statistics

Norway, Statistics Iceland and the Human Mortality database for providing data for this study.

Funding: The research leading to these results was carried out as part of the Social Inequalities in Ageing (SIA) project, funded by NordForsk, project no. 74637.

Conflict of Interest: The authors declare that they have no conflict of interest.

\section{REFERENCES}

1. WHO. World report on aging and health. Luxemourg: World_Health_Organization; 2015.

2. Christensen K, Doblhammer G, Rau R, Vaupel JW. Ageing populations: the challenges ahead. Lancet. 2009;374(9696):1196-208.

3. NIA, NIH. Global Health and Aging. USA: National Institut on Aging \& National Institut of Health; 2011.

4. Magnussen J VK, Saltman RB. Nordic Health Care Systems - Recent Reforms and Current Policy Challenges England: European Observatory on Health Systems and Policies Series; 2009.

5. Vallgarda S. Addressing individual behaviours and living conditions: four Nordic public health policies. Scand J Public Health. 2011;39(6 Suppl):6-10. doi: .1177/1403494810378922.

6. Trydegård G. Care work in changing welfare states: Nordic care workers' experiences. Eur J Aging. 2012;9(2):10.

7. Lundberg O, Yngwe MA, Stjarne MK, Elstad JI, Ferrarini T, Kangas O, et al. The role of welfare state principles and generosity in social policy programmes for public health: an international comparative study. Lancet. 2008;372(9650):1633-40. doi: 10.016/S0140-6736(08)61686-4.

8. Ogg J. Social exclusion and insecurity among older Europeans: the influence of welfare regimes. Aging \& Society. 2005;25:69-90.

9. Wilmoth JR, Andreev K, Jdanov D, Glei DA. Methods Protocol for the Human Mortality Database. the Human Mortality Database; 2007.

10. Arriaga EE. Measuring and explaining the change in life expectancies. Demography. 1984;21(1):83-96.

11. Preston SHH, P.; Guillot, M.;. Demography: measuring and modeling population processes.: Oxford: Blackwell; 2001.

12. Bavel J, Reher D. The Baby Boom and Its Causes: What We Know and What We Need to Know. Population and development review. 2013;39(2):31.

13. Andersson G, Ronsen M, Knudsen L, Lappegard T, Neyer G, Skrede K, et al. Cohort fertility patterns in the Nordic countries. Demographic research. 2009;20(14):39.

14. OECD. International Migration Database OECD.stat: OECD; 2016 [Available from: https://stats.oecd.org/Index.aspx?DataSetCode=MIG\#.

15. Vollset SE. Risk and causes of death between 40 and 70 years of age in the Nordic countries 1951-2010. Scand J Public Health. 2013;41(6):644-51. doi: 10.1177/1403494813491032. Epub 2013 Jun 11.

16. Engeland A, Haldorsen T, Dickman PW, Hakulinen T, Moller TR, Storm HH, et al. Relative survival of cancer patients--a comparison between Denmark and the other Nordic countries. Acta Oncol. 1998;37(1):49-59.

17. Jacobsen R, Von Euler M, Osler M, Lynge E, Keiding N. Women's death in Scandinavia--what makes Denmark different? Eur J Epidemiol. 2004;19(2):117-21.

18. PMO. War victims in Finland 1914-22 Finland: Prime Minister's Office; 2016 [Available from: http://vesta.narc.fi/cgi-bin/db2www/sotasurmaetusivu/stat2. 
19. NAS. Suomen sodissa 1939-1945 menehtyneet Finland: The National Archives Service; 2016 [Available from: http://kronos.narc.fi/menehtyneet/index.php?kuol_a_p=1\&kuol_a_v=1918\&kuol_a_k=1\&kuol_1_p=31\&kuol_1_v $=1945 \&$ kuol_1_k=12\&kunta $=* \&$ haekaikki $=0 \&$ sort $=$ kaikki\&sivulle $=20 \& \mathrm{i}=20$.

20. Beltran-Sanchez H, Finch CE, Crimmins EM. Twentieth century surge of excess adult male mortality. Proc Natl Acad Sci U S A. 2015;112(29):8993-8. doi: 10.1073/pnas.1421942112. Epub 2015 Jul 6.

21. OECD. Daily smokers (indicator). 2016 [Available from: https://data.oecd.org/healthrisk/daily-smokers.htm.

22. Österberg EM, P. Alcohol use in Finland Finland: Addictionlink.fi; 2009 [Available from: http://www.paihdelinkki.fi/en/info-bank/articles/alcohol/alcohol-use-finland.

23. Thorslund M, Wastesson JW, Agahi N, Lagergren M, Parker MG. The rise and fall of women's advantage: a comparison of national trends in life expectancy at age 65 years. Eur J Ageing. 2013;10(4):271-7.

24. Luy M, Wegner-Siegmundt C. The impact of smoking on gender differences in life expectancy: more heterogeneous than often stated. Eur J Public Health. 2015;25(4):706-10. doi: 10.1093/eurpub/cku211. Epub 2014 Dec 10. 
Table 1 Number and proportions of the population aged 75+ and 90+ years by gender in 1990 and 2014 based on data from the countries' national statistical databases (http://dst.dk/, http://www.scb.se/, http://www.ssb.no/, http://www.statice.is/, ttp://www.stat.fi/).

\begin{tabular}{|l|l|r|r|r|r|}
\hline & & \multicolumn{2}{|c|}{ Females } & \multicolumn{2}{c|}{ Males } \\
\hline & & \multicolumn{1}{|c|}{$\mathbf{1 9 9 0}$} & \multicolumn{1}{c|}{$\mathbf{2 0 1 4}$} & \multicolumn{1}{c|}{$\mathbf{1 9 9 0}$} & \multicolumn{1}{c|}{$\mathbf{2 0 1 4}$} \\
\hline \multirow{4}{*}{$\geq \mathbf{7 5}$ years } & & \multicolumn{4}{|c|}{ Numbers (\%) } \\
& Iceland & $6,755(5.3)$ & $10,973(6.8)$ & $4,671(3.7)$ & $8,418(5.2)$ \\
\cline { 2 - 6 } & Finland & $193,988(7.6)$ & $292,699(11.2)$ & $84,736(3.5)$ & $176,607(7.0)$ \\
\cline { 2 - 6 } & Norway & $187,275(8.8)$ & $213,610(8.4)$ & $109,513(5.2)$ & $141,500(5.5)$ \\
\cline { 2 - 6 } & Denmark & $226,199(8.7)$ & $246,105(8.7)$ & $129,931(5.1)$ & $168,950(5.5)$ \\
\cline { 2 - 6 } & Sweden & $425,867(9.8)$ & $488,575(10.0)$ & $262,997(6.2)$ & $345,914(7.1)$ \\
\hline \multirow{5}{*}{$\mathbf{9 0}$ years } & Iceland & $625(0.5)$ & $1,244(0.8)$ & $306(0.2)$ & $589(0.4)$ \\
\cline { 2 - 6 } & Finland & $10,091(0.4)$ & $32,693(1.2)$ & $2,669(0.1)$ & $9,734(0.4)$ \\
\cline { 2 - 6 } & Norway & $13,543(0.6)$ & $31,128(1.2)$ & $5,359()$ & $11,267()$ \\
\cline { 2 - 6 } & Denmark & $16,482(0.6)$ & $30,703(1.1)$ & $6,044(0.2)$ & $10,822(0.4)$ \\
\cline { 2 - 6 } & Sweden & $30,532(0.7)$ & $67,086(1.4)$ & $11,044(0.3)$ & $27,910(0.6)$ \\
\hline
\end{tabular}


Table 2 Contribution of each age group to the total change in gender-specific life expectancy at age 75 years from 1990 to 2012 and to the total difference between female and male life expectancy at age 75 years in 2012 in years (\%) based on data from period life tables available from the Human Mortality Database (http://www.mortality.org/).

\begin{tabular}{|c|c|c|c|c|c|c|c|c|c|c|c|c|c|c|c|}
\hline & \multicolumn{5}{|c|}{ Females (2012 vs. 1990) } & \multicolumn{5}{|c|}{ Males (2012 vs. 1990) } & \multicolumn{5}{|c|}{ Gender difference in 2012} \\
\hline Age groups & DK & SE & FI & NO & IS & DK & SE & FI & NO & IS & DK & SE & FI & NO & IS \\
\hline 75-79 years & $\begin{array}{r}0.55 \\
(36.5)\end{array}$ & $\begin{array}{r}0.58 \\
(37.0)\end{array}$ & $\begin{array}{r}1.11 \\
(40.5)\end{array}$ & $\begin{array}{r}0.76 \\
(39.6)\end{array}$ & $\begin{array}{r}0.92 \\
(92.7)\end{array}$ & $\begin{array}{r}1.16 \\
(55.6)\end{array}$ & $\begin{array}{r}1.11 \\
(54.2)\end{array}$ & $\begin{array}{r}1.41 \\
(55.3)\end{array}$ & $\begin{array}{r}1.24 \\
(55.8)\end{array}$ & $\begin{array}{r}1.24 \\
(67.1)\end{array}$ & $\begin{array}{r}0.75 \\
(37.7)\end{array}$ & $\begin{array}{r}0.70 \\
(35.3)\end{array}$ & $\begin{array}{r}1.02 \\
(41.8)\end{array}$ & $\begin{array}{r}0.77 \\
(35.9)\end{array}$ & $\begin{array}{r}0.36 \\
(29.2)\end{array}$ \\
\hline 80-84 years & $\begin{array}{r}0.38 \\
(25.0)\end{array}$ & $\begin{array}{r}0.58 \\
(37.1) \\
\end{array}$ & $\begin{array}{r}0.98 \\
(35.7)\end{array}$ & $\begin{array}{r}0.67 \\
(34.5) \\
\end{array}$ & $\begin{array}{l}-0.05 \\
(-5.2)\end{array}$ & $\begin{array}{r}0.65 \\
(30.9) \\
\end{array}$ & $\begin{array}{r}0.65 \\
(32.0)\end{array}$ & $\begin{array}{r}0.77 \\
(30.3)\end{array}$ & $\begin{array}{r}0.67 \\
(30.2)\end{array}$ & $\begin{array}{r}0.54 \\
(29.6) \\
\end{array}$ & $\begin{array}{r}0.58 \\
(29.1)\end{array}$ & $\begin{array}{r}0.69 \\
(34.6) \\
\end{array}$ & $\begin{array}{r}0.81 \\
(33.4)\end{array}$ & $\begin{array}{r}0.76 \\
(35.9) \\
\end{array}$ & $\begin{array}{r}0.40 \\
(32.4) \\
\end{array}$ \\
\hline 85-89 years & $\begin{array}{r}0.41 \\
(26.8) \\
\end{array}$ & $\begin{array}{r}0.30 \\
(19.2) \\
\end{array}$ & $\begin{array}{r}0.51 \\
(18.7) \\
\end{array}$ & $\begin{array}{r}0.40 \\
(21.0)\end{array}$ & $\begin{array}{l}0.03 \\
(3.0)\end{array}$ & $\begin{array}{r}0.23 \\
(10.9)\end{array}$ & $\begin{array}{r}0.25 \\
(12.4)\end{array}$ & $\begin{array}{r}0.31 \\
(12.3)\end{array}$ & $\begin{array}{r}0.27 \\
(12.0)\end{array}$ & $\begin{array}{c}0.13 \\
(7.0)\end{array}$ & $\begin{array}{r}0.45 \\
(22.9) \\
\end{array}$ & $\begin{array}{r}0.42 \\
(20.9)\end{array}$ & $\begin{array}{r}0.44 \\
(18.3)\end{array}$ & $\begin{array}{r}0.42 \\
(19.9)\end{array}$ & $\begin{array}{r}0.29 \\
(24.2)\end{array}$ \\
\hline 90-94 years & $\begin{array}{r}0.14 \\
(9.0) \\
\end{array}$ & $\begin{array}{r}0.10 \\
(6.1) \\
\end{array}$ & $\begin{array}{r}0.13 \\
(4.7) \\
\end{array}$ & $\begin{array}{r}0.09 \\
(4.6) \\
\end{array}$ & $\begin{array}{l}0.06 \\
(6.3) \\
\end{array}$ & $\begin{array}{c}0.05 \\
(2.4) \\
\end{array}$ & $\begin{array}{r}0.03 \\
(1.4) \\
\end{array}$ & $\begin{array}{r}0.05 \\
(1.9) \\
\end{array}$ & $\begin{array}{r}0.04 \\
(1.9) \\
\end{array}$ & $\begin{array}{l}-0.03 \\
(-1.5) \\
\end{array}$ & $\begin{array}{r}0.16 \\
(8.2) \\
\end{array}$ & $\begin{array}{r}0.16 \\
(7.8) \\
\end{array}$ & $\begin{array}{r}0.14 \\
(5.8) \\
\end{array}$ & $\begin{array}{r}0.16 \\
(7.3) \\
\end{array}$ & $\begin{array}{r}0.14 \\
(11.3) \\
\end{array}$ \\
\hline$\geq 95$ years & $\begin{array}{l}0.04 \\
(2.7)\end{array}$ & $\begin{array}{c}0.01 \\
(0.6) \\
\end{array}$ & $\begin{array}{l}0.01 \\
(0.4) \\
\end{array}$ & $\begin{array}{l}0.01 \\
(0.3) \\
\end{array}$ & $\begin{array}{l}0.03 \\
(3.2) \\
\end{array}$ & $\begin{array}{r}0.00 \\
(0.2) \\
\end{array}$ & $\begin{array}{l}0.00 \\
(0.0) \\
\end{array}$ & $\begin{array}{l}0.01 \\
(0.2) \\
\end{array}$ & $\begin{array}{l}0.00 \\
(0.1) \\
\end{array}$ & $\begin{array}{l}-0.04 \\
(-2.2) \\
\end{array}$ & $\begin{array}{l}0.04 \\
(2.1)\end{array}$ & $\begin{array}{r}0.03 \\
(1.30) \\
\end{array}$ & $\begin{array}{l}0.02 \\
(0.7) \\
\end{array}$ & $\begin{array}{c}0.02 \\
(1.0)\end{array}$ & $\begin{array}{c}0.03 \\
(2.9) \\
\end{array}$ \\
\hline $\begin{array}{l}75 \text { years } \\
\text { (total) }\end{array}$ & $\begin{array}{r}1.52 \\
(100.0)\end{array}$ & $\begin{array}{r}1.57 \\
(100.0)\end{array}$ & $\begin{array}{r}2.75 \\
(100.0)\end{array}$ & $\begin{array}{r}1.93 \\
(100.0)\end{array}$ & $\begin{array}{r}0.99 \\
(100.0)\end{array}$ & $\begin{array}{c}2.09 \\
(100.0)\end{array}$ & $\begin{array}{r}2.04 \\
(100.0)\end{array}$ & $\begin{array}{r}2.55 \\
(100.0)\end{array}$ & $\begin{array}{r}2.22 \\
(100.0)\end{array}$ & $\begin{array}{r}1.84 \\
(100.0)\end{array}$ & $\begin{array}{r}1.98 \\
(100.0)\end{array}$ & $\begin{array}{r}2.00 \\
(100.0)\end{array}$ & $\begin{array}{r}2.43 \\
(100.0)\end{array}$ & $\begin{array}{r}2.13 \\
(100.0)\end{array}$ & $\begin{array}{r}1.22 \\
(100.0)\end{array}$ \\
\hline
\end{tabular}



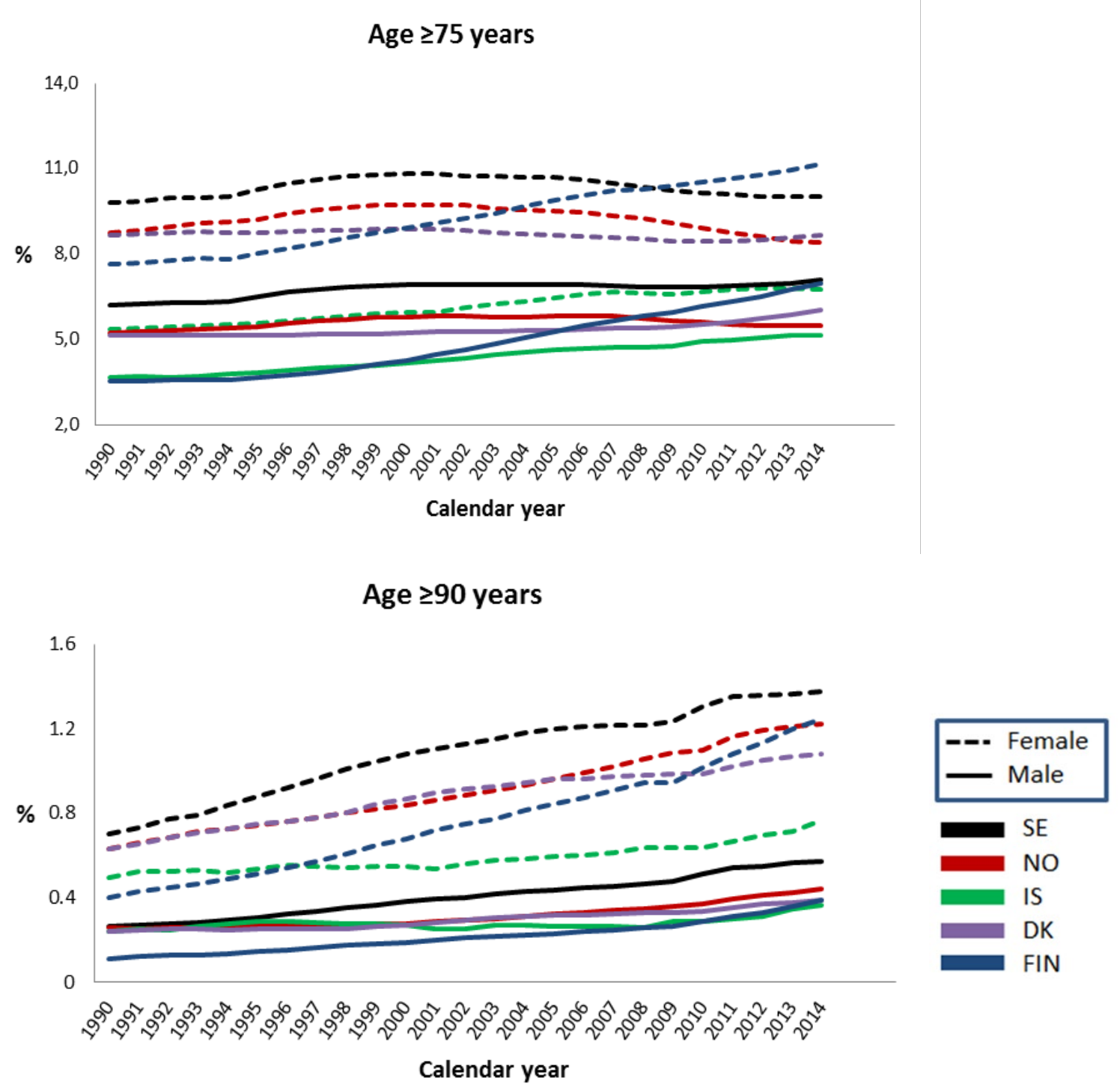

Figure 1 Proportions of the population aged 75+ and 90+ years by gender (note: different y-axes) based on data from the countries' national statistical databases (http://dst.dk/, http://www.scb.se/, http://www.ssb.no/, http://www.statice.is/, ttp://www.stat.fi/). 


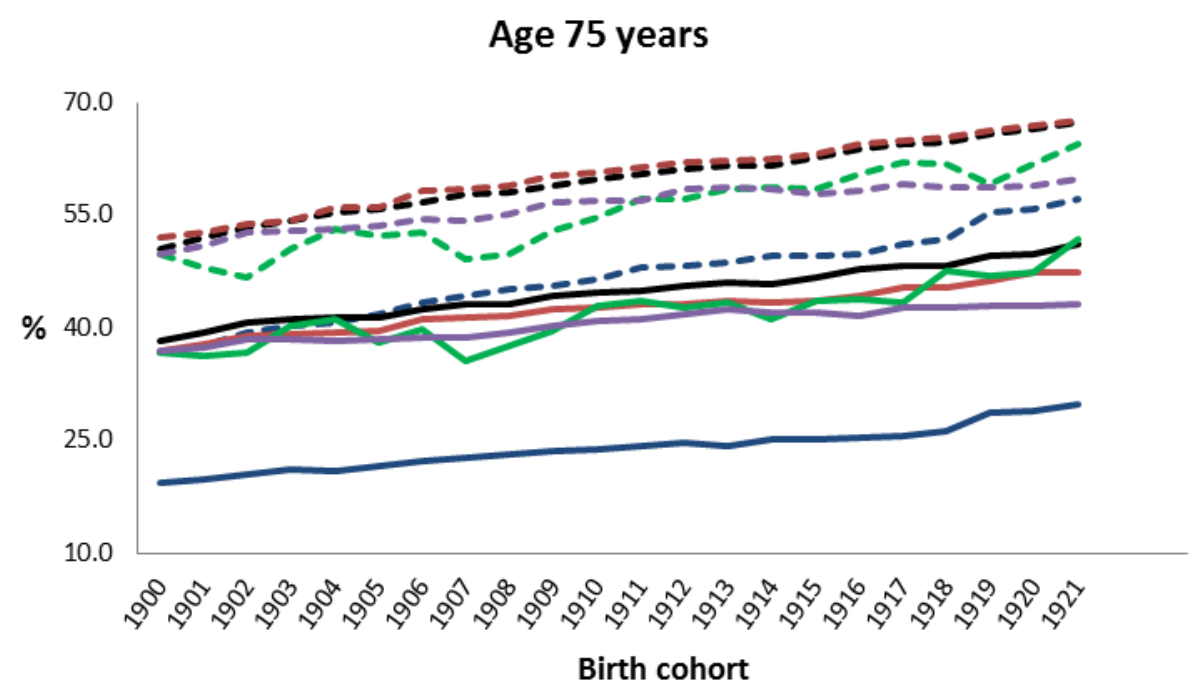

Age 90 years

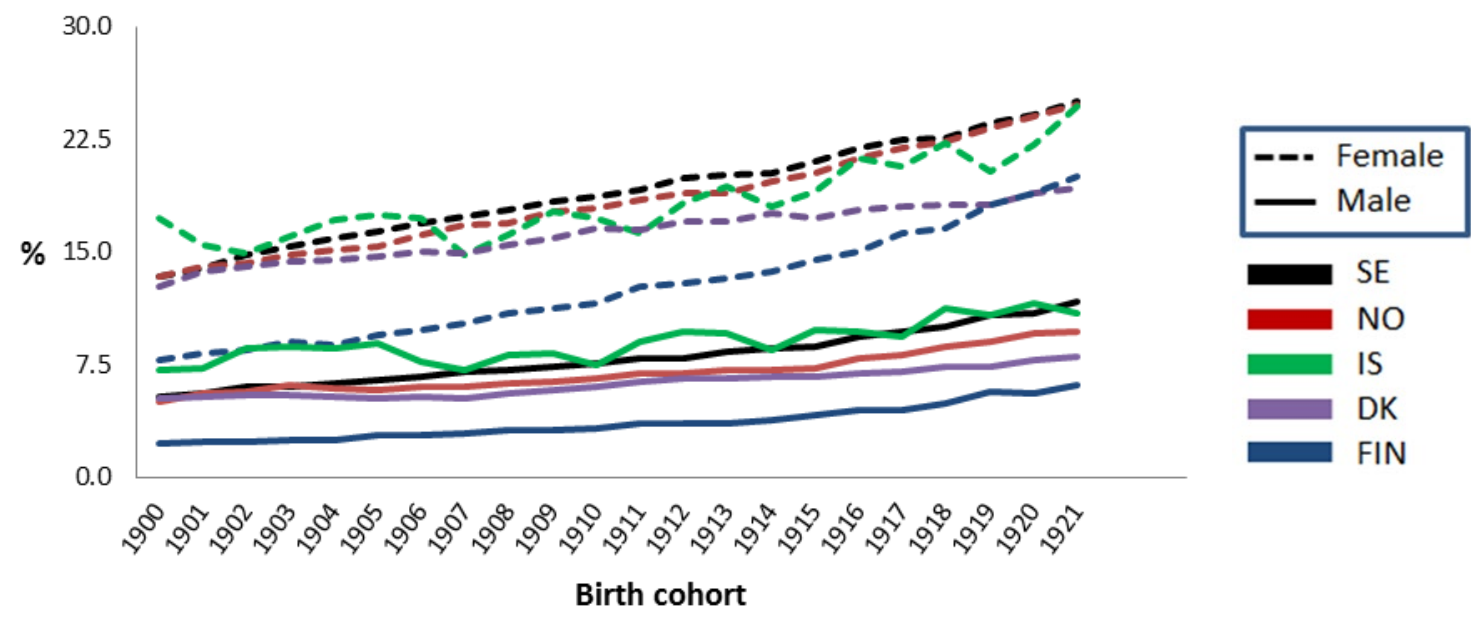

Figure 2 Proportions of birth cohorts reaching age 75 and 90 years by gender (note: different y-axes) based on cohort life tables available from the Human Mortality Database (http://www.mortality.org/). 


\section{Age 75 years}

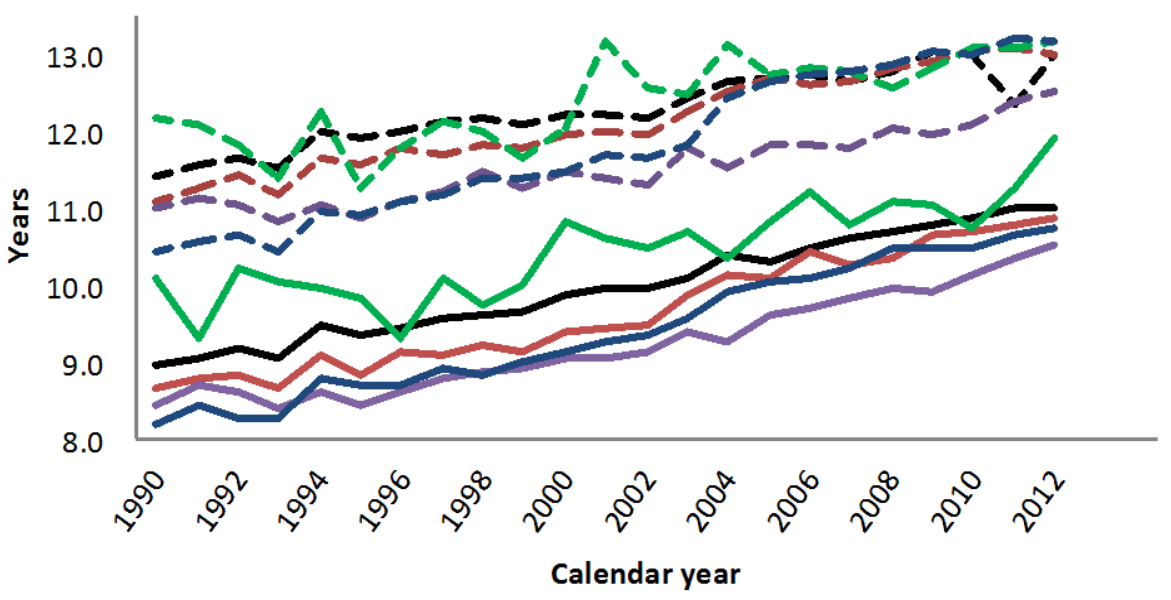

\section{Age 90 years}

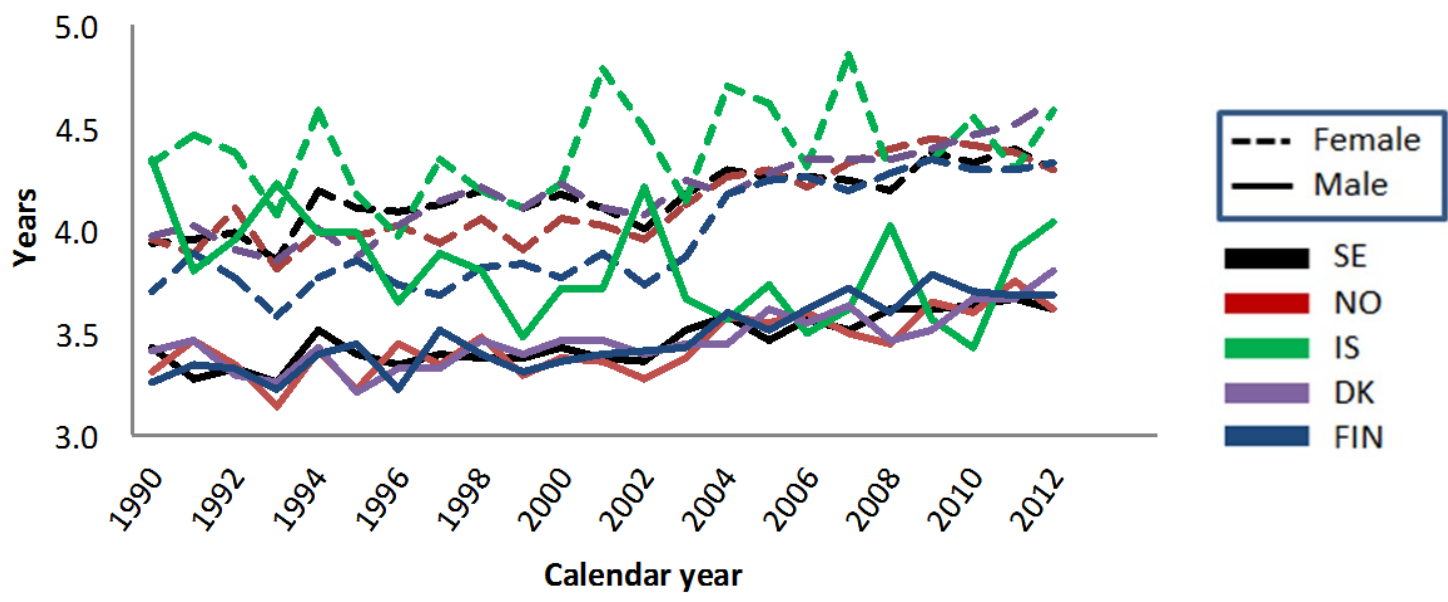

Figure 3 Life expectancy at age 75 and 90 years by gender (note: different y-axes) based on data from period life tables available from the Human Mortality Database (http://www.mortality.org/). 
Supplementary Table A1 Proportions of population age 75 and 90 years by country

\begin{tabular}{|l|l|l|l|l|l|l|l|l|l|l|l|l|l|l|l|l|l|l|l|l|l|l|l|l|}
\hline 1990 & 1991 & 1992 & 1993 & 1994 & 1995 & 1996 & 1997 & 1998 & 1999 & 2000 & 2001 & 2002 & 2003 & 2004 & 2005 & 2006 & 2007 & 2008 & 2009 & 2019 & 2011 & 2012 & 2013 & 2014 \\
\hline
\end{tabular}

\section{Females}

75 years

\begin{tabular}{|c|c|c|c|c|c|c|c|c|c|c|c|c|c|c|c|c|c|c|c|c|c|c|c|c|c|}
\hline we & & 99 & 100 & 100 & 100 & 103 & 105 & 106 & 107 & 108 & 108 & 108 & 108 & 107 & 107 & 107 & 106 & 105 & 104 & 102 & 101 & 101 & 100 & 100 & 10.0 \\
\hline Nor & 8.8 & 89 & 9.0 & 9.1 & 9.2 & 9.2 & 9.4 & 9.6 & 9.7 & 9.7 & 9.7 & 9.7 & 9.7 & 9.6 & 9.6 & 9.5 & 9.5 & 9.4 & 9.2 & 9.1 & 8.9 & 8.7 & 8.6 & 8.5 & 8.4 \\
\hline Iceland & 5.3 & 5.4 & 5.4 & 5.5 & 5.5 & 5.6 & 5.7 & 5.7 & 5.8 & 5.9 & 5.9 & 6.0 & 6.1 & 6.2 & 6.3 & 6.5 & 6.6 & 6.7 & 6.6 & 6.6 & 6.7 & 6.7 & 6.8 & 6.8 & 6.8 \\
\hline Denmark & 8.7 & 8.7 & 8.8 & 8.8 & 8.8 & 8.7 & 8.8 & 8.8 & 8.8 & 8.9 & 8.9 & 8.9 & 8.8 & 8.7 & 8.7 & 8.7 & 8.6 & 8.6 & 8.5 & 8.5 & 8.4 & 8.4 & 8.5 & 8.6 & 8.7 \\
\hline Finland & 7.6 & 7.7 & 7.8 & 7.9 & 7.8 & 8.0 & 8.2 & 8.4 & 8.6 & 8.7 & 8.9 & 9.1 & 9.2 & 9.4 & 9.7 & 9.9 & 10.1 & 10.2 & 10.3 & 10.4 & 10.5 & 10.7 & 10.8 & 11.0 & 11.2 \\
\hline
\end{tabular}

90 years

\begin{tabular}{|c|c|c|c|c|c|c|c|c|c|c|c|c|c|c|c|c|c|c|c|c|c|c|c|c|c|}
\hline & & & & & & & & & & & & & & & & & & & & & & & & & \\
\hline Sweden & 0.7 & 0.7 & 0.8 & 0.8 & 0.8 & 0.9 & 0.9 & 1.0 & 1.0 & 1.0 & 1.1 & 1.1 & 1.1 & 1.2 & 1.2 & 1.2 & 1.2 & 1.2 & 1.2 & 1.2 & 1.3 & 1.4 & 1.4 & 1.34 & 1.4 \\
\hline Norway & 0.6 & 0.7 & 0.7 & 0.7 & 0.7 & 0.7 & 0.8 & 0.8 & 0.8 & 0.8 & 0.8 & 0.9 & 0.9 & 0.9 & 0.9 & 1.0 & 1.0 & 1.0 & 1.1 & 1.1 & 1.1 & 1.2 & 1.2 & 1.2 & 1.2 \\
\hline Iceland & 0.5 & 0.5 & 0.5 & 0.5 & 0.5 & 0.5 & 0.6 & 0.5 & 0.5 & 0.5 & 0.5 & 0.5 & 0.6 & 0.6 & 0.6 & 0.6 & 0.6 & 0.6 & 0.6 & 0.6 & 0.6 & 0.7 & 0.7 & 0.7 & 0.8 \\
\hline Denmark & 0.6 & 0.7 & 0.7 & 0.7 & 0.7 & 0.8 & 0.8 & 0.8 & 0.8 & 0.8 & 0.9 & 0.9 & 0.9 & 0.9 & 0.9 & 1.0 & 1.0 & 1.0 & 1.0 & 1.0 & 1.0 & 1.0 & 1.1 & 1.1 & 1.1 \\
\hline Finland & 0.4 & 0.4 & 0.4 & 0.5 & 0.5 & 0.5 & 0.5 & 0.6 & 0.6 & 0.6 & 0.7 & 0.7 & 0.7 & 0.8 & 0.8 & 0.8 & 0.9 & 0.9 & 0.9 & 0.9 & 1.0 & 1.1 & 1.1 & 1.2 & 1.2 \\
\hline
\end{tabular}

Males

\begin{tabular}{|c|c|c|c|c|c|c|c|c|c|c|c|c|c|c|c|c|c|c|c|c|c|c|c|c|c|}
\hline \multicolumn{26}{|c|}{75 years } \\
\hline Sweden & 6.2 & 6.2 & 6.3 & 6.3 & 6.3 & 6.5 & 6.7 & 6.8 & 6.8 & 6.9 & 6.9 & 7.0 & 6.9 & 6.9 & 6.9 & 6.9 & 6.9 & 6.9 & 6.9 & 6.8 & 6.8 & 6.9 & 6.9 & 7.0 & 7.1 \\
\hline Norway & 5.2 & 5.3 & 5.3 & 5.4 & 5.4 & 5.4 & 5.6 & 5.7 & 5.7 & 5.8 & 5.8 & 5.8 & 5.8 & 5.8 & 5.8 & 5.8 & 5.8 & 5.8 & 5.8 & 5.7 & 5.6 & 5.6 & 5.5 & 5.5 & 5.5 \\
\hline Iceland & 3.7 & 3.7 & 3.7 & 3.7 & 3.8 & 3.8 & 3.9 & 4.0 & 4.1 & 4.1 & 4.2 & 4.2 & 4.3 & 4.5 & 4.6 & 4.7 & 4.7 & 4.7 & 4.7 & 4.8 & 4.9 & 5.0 & 5.0 & 5.2 & 5.2 \\
\hline Denmark & 5.1 & 5.1 & 5.2 & 5.2 & 5.1 & 5.1 & 5.2 & 5.2 & 5.2 & 5.2 & 5.2 & 5.3 & 5.3 & 5.3 & 5.3 & 5.3 & 5.4 & 5.4 & 5.4 & 5.5 & 5.5 & 5.6 & 5.7 & 5.9 & 6.1 \\
\hline Finland & 3.5 & 3.6 & 3.6 & 3.6 & 3.6 & 3.7 & 3.8 & 3.9 & 4.0 & 4.1 & 4.3 & 4.5 & 4.6 & 4.8 & 5.1 & 5.3 & 5.5 & 5.7 & 5.8 & 6.0 & 6.2 & 6.3 & 6.5 & 6.8 & 7.0 \\
\hline \multicolumn{26}{|c|}{90 years } \\
\hline Sweden & 0.3 & 0.3 & 0.3 & 0.3 & 0.3 & 0.3 & 0.3 & 0.3 & 0.4 & 0.4 & 0.4 & 0.4 & 0.4 & 0.4 & 0.4 & 0.4 & 0.4 & 0.5 & 0.5 & 0.5 & 0.56 & 0.5 & 0.6 & 0.6 & 0.6 \\
\hline Norway & 0.3 & 0.3 & 0.3 & 0.3 & 0.3 & 0.3 & 0.3 & 0.3 & 0.3 & 0.3 & 0.3 & 0.3 & 0.3 & 0.3 & 0.3 & 0.3 & 0.3 & 0.3 & 0.3 & 0.4 & 0.4 & 0.4 & 0.4 & 0.4 & 0.4 \\
\hline Iceland & 0.2 & 0.2 & 0.2 & 0.3 & 0.3 & 0.3 & 0.3 & 0.3 & 0.3 & 0.3 & 0.3 & 0.2 & 0.2 & 0.3 & 0.3 & 0.3 & 0.3 & 0.3 & 0.3 & 0.3 & 0.3 & 0.3 & 0.3 & 0.3 & 0.4 \\
\hline Denmark & 0.2 & 0.2 & 0.2 & 0.2 & 0.2 & 0.3 & 0.2 & 0.3 & 0.3 & 0.3 & 0.3 & 0.3 & 0.3 & 0.3 & 0.3 & 0.3 & 0.3 & 0.3 & 0.3 & 0.3 & 0.3 & 0.4 & 0.4 & 0.4 & 0.4 \\
\hline Finland & 0.1 & 0.1 & 0.1 & 0.1 & 0.1 & 0.1 & 0.2 & 0.2 & 0.2 & 0.2 & 0.2 & 0.2 & 0.2 & 0.2 & 0.2 & 0.2 & 0.2 & 0.2 & 0.2 & 0.3 & 0.3 & 0.3 & 0.3 & 0.4 & 0.4 \\
\hline
\end{tabular}


Supplementary Table A2 Proportions of gender-specific birth cohorts reaching age 75 and 90 years by country

\begin{tabular}{|c|c|c|c|c|c|c|c|c|c|c|c|c|c|c|c|c|c|c|c|c|c|c|c|c|}
\hline & 1900 & 1901 & 1902 & 1903 & 1904 & 1905 & 1906 & 1907 & 1908 & 1909 & 1910 & 1911 & 1912 & 2013 & 1914 & 1915 & 1916 & 1917 & 1918 & 1919 & 1920 & 1921 & 1922 & 1923 \\
\hline \multicolumn{25}{|c|}{ Females } \\
\hline \multicolumn{25}{|c|}{75 years } \\
\hline Sweden & 50.5 & 51.9 & 53.4 & 54.2 & 55.3 & 55.8 & 56.6 & 57.9 & 58.0 & 59.0 & 59.8 & 60.5 & 61.2 & 61.7 & 61.7 & 62.7 & 63.9 & 64.5 & 64.8 & 65.9 & 66.5 & 67.5 & 67.8 & 68.4 \\
\hline Norway & 52.0 & 52.7 & 53.9 & 54.4 & 56.1 & 56.0 & 58.4 & 58.5 & 58.9 & 60.2 & 60.7 & 61.5 & 62.0 & 62.2 & 62.6 & 63.1 & 64.5 & 64.9 & 65.3 & 66.2 & 67.0 & 67.6 & 68.1 & 68.4 \\
\hline Iceland & 49.9 & 48.1 & 46.7 & 50.6 & 53.3 & 52.3 & 52.8 & 49.1 & 49.9 & 52.9 & 54.8 & 57.1 & 57.5 & 58.6 & 58.8 & 58.5 & 60.4 & 62.0 & 61.8 & 59.1 & 61.8 & 64.6 & 64.8 & \\
\hline Denmark & 49.9 & 50.9 & 52.6 & 52.9 & 53.1 & 53.7 & 54.6 & 54.4 & 55.2 & 56.7 & 57.0 & 57.0 & 58.4 & 58.6 & 58.4 & 57.9 & 58.4 & 59.1 & 58.6 & 58.7 & 59.0 & 59.8 & 59.4 & 59.7 \\
\hline Finland & 36.8 & 37.6 & 39.4 & 40.3 & 40.7 & 41.8 & 43.4 & 44.3 & 45.2 & 45.6 & 46.4 & 48.1 & 48.3 & 48.8 & 49.5 & 49.6 & 49.9 & 51.2 & 51.9 & 55.3 & 55.9 & 57.1 & & \\
\hline \multicolumn{25}{|c|}{90 years } \\
\hline Sweden & 13.4 & 13.9 & 14.8 & 15. & 15.9 & 16.4 & 16.9 & 17.4 & 17.8 & 18.3 & 18.7 & 19.2 & 19.9 & 20.2 & 20.3 & 21.0 & 21.9 & 22.4 & 22.6 & 23.6 & 24.1 & 25.0 & 24.9 & 25.8 \\
\hline Norway & 13.4 & 14.0 & 14.2 & 14.8 & 15.2 & 15.4 & 16.2 & 16.8 & 16.9 & 17.7 & 17.9 & 18.5 & 18.9 & 19.0 & 19.7 & 20.2 & 21.3 & 21.9 & 22.3 & 23.2 & 24.1 & 24.8 & 25.6 & 25.6 \\
\hline Iceland & 17.2 & 15.5 & 15.0 & 16.1 & 17.1 & 17.5 & 17.2 & 14.8 & 16.1 & 17.6 & 17.3 & 16.3 & 18.3 & 19.4 & 18.1 & 19.0 & 21.2 & 20.6 & 22.2 & 20.3 & 22.1 & 24.7 & 23.2 & \\
\hline Denmark & 12.7 & 13.7 & 14.1 & 14.4 & 14.5 & 14.7 & 15.0 & 14.9 & 15.5 & 15.9 & 16.6 & 16.5 & 17.1 & 17.1 & 17.5 & 17.3 & 17.9 & 18.1 & 18.2 & 18.2 & 19.0 & 19.3 & 19.3 & 19.9 \\
\hline Finland & 7.8 & 8.3 & 8.5 & 9.0 & 8.9 & 9.5 & 9.8 & 10.3 & 10.9 & 11.3 & 11.6 & 12.7 & 13.0 & 13.3 & 13.7 & 14.5 & 15.1 & 16.3 & 16.6 & 18.1 & 18.9 & 20.0 & & \\
\hline \multicolumn{25}{|c|}{ Males } \\
\hline \multicolumn{25}{|c|}{75 years } \\
\hline Sweden & 38.3 & 39.4 & 40.7 & 41.1 & 41.5 & 41.5 & 42.5 & 43.3 & 43.2 & 44.2 & 44.8 & 45.0 & 45.6 & 46.1 & 45.9 & 46.7 & 47.8 & 48.3 & 48.2 & 49.6 & 49.8 & 51.3 & 51.4 & 52.6 \\
\hline Norway & 37.0 & 37.9 & 38.9 & 39.1 & 39.5 & 39.6 & 41.3 & 41.3 & 41.6 & 42.6 & 42.7 & 43.2 & 43.2 & 43.5 & 43.4 & 43.5 & 44.4 & 45.5 & 45.3 & 46.3 & 47.3 & 47.34 & 48.2 & 49.5 \\
\hline Iceland & 36.8 & 36.2 & 36.7 & 40.3 & 41.1 & 38.1 & 39.9 & 35.6 & 37.6 & 39.7 & 42.9 & 43.6 & 42.8 & 43.3 & 41.1 & 43.6 & 43.8 & 43.5 & 47.6 & 47.0 & 47.4 & 51.8 & 49.8 & \\
\hline Denmark & 36.9 & 37.4 & 38.5 & 38.4 & 38.3 & 38.6 & 38.8 & 38.6 & 39.3 & 40.3 & 41.0 & 41.3 & 41.9 & 42.4 & 42.1 & 42 & 41.7 & 42.8 & 42.7 & 43.0 & 42.9 & 43.1 & 43.2 & 43.6 \\
\hline Finland & 19.3 & 19.9 & 20.6 & 21.1 & 21.0 & 21.5 & 22.4 & 22.7 & 23.2 & 23.7 & 23.8 & 24.4 & 24.7 & 24.4 & 25.2 & 25.2 & 25.3 & 25.7 & 26.2 & 28.6 & 28.9 & 29.9 & & \\
\hline \multicolumn{25}{|c|}{90 years } \\
\hline Sweden & 5.4 & 5.6 & 6.0 & 6.1 & 6.3 & 6.5 & 6.7 & 7.0 & 7.1 & 7.3 & 7.6 & 7.9 & 7.9 & 8.3 & 8.6 & 8.7 & 9.4 & 9.7 & 10.0 & 10.8 & 10.9 & 11.7 & 11.9 & 12.6 \\
\hline Norway & 5.1 & 5.6 & 5.7 & 6.1 & 5.9 & 5.8 & 6.1 & 6.1 & 6.2 & 6.3 & 6.6 & 6.9 & 6.9 & 7.2 & 7.2 & 7.3 & 7.9 & 8.2 & 8.7 & 9.1 & 9.6 & 9.7 & 10.6 & 10.9 \\
\hline Iceland & 7.1 & 7.3 & 8.6 & 8.7 & 8.6 & 9.0 & 7.7 & 7.2 & 8.1 & 8.3 & 7.4 & 9.2 & 9.8 & 9.6 & 8.4 & 9.8 & 9.7 & 9.4 & 11.2 & 10.8 & 11.6 & 11.0 & 14.6 & \\
\hline Denmark & 5.3 & 5.3 & 5.5 & 5.5 & 5.4 & 5.3 & 5.4 & 5.3 & 5.6 & 5.8 & 6.1 & 6.3 & 6.6 & 6.5 & 6.7 & 6.7 & 7.0 & 7.1 & 7.4 & 7.4 & 7.8 & 8.1 & 8.2 & 8.5 \\
\hline Finland & 2.2 & 2.4 & 2.3 & 2.5 & 2.5 & 2.8 & 2.8 & 2.9 & 3.2 & 3.1 & 3.2 & 3.6 & 3.6 & 3.7 & 3.8 & 4.1 & 4.5 & 4.5 & 4.9 & 5.7 & 5.6 & 6.2 & & \\
\hline
\end{tabular}


Supplementary Table A3 Life expectancy at age 75 and 90 years by country

\begin{tabular}{|c|c|c|c|c|c|c|c|c|c|c|c|c|c|c|c|c|c|c|c|c|c|c|c|}
\hline & 1990 & 1991 & 1992 & 1993 & 1994 & 1995 & 1996 & 1997 & 1998 & 1999 & 2000 & 2001 & 2002 & 2003 & 2004 & 2005 & 2006 & 2007 & 2008 & 2009 & 2019 & 2011 & 2012 \\
\hline \multicolumn{24}{|c|}{ Females } \\
\hline \multicolumn{24}{|c|}{75 years } \\
\hline Sweden & 11.4 & 11.6 & 11.7 & 11.5 & 12.0 & 11.9 & 12.0 & 12.1 & 12.2 & 12.1 & 12.2 & 12.2 & 12.2 & 12.4 & 12.6 & 12.7 & 12.7 & 12.7 & 12.8 & 13.0 & 13.0 & 12.4 & 13.0 \\
\hline Norway & 11.1 & 11.3 & 11.4 & 11.2 & 11.6 & 11.6 & 11.8 & 11.7 & 11.8 & 11.8 & 11.9 & 12.0 & 12.0 & 12.3 & 12.5 & 12.7 & 12.6 & 12.7 & 12.8 & 12.9 & 13.0 & 13.1 & 13.0 \\
\hline Iceland & 12.2 & 12.1 & 11.8 & 11.4 & 12.3 & 11.3 & 11.8 & 12.1 & 12.0 & 11.7 & 12.0 & 13.2 & 12.6 & 12.5 & 13.1 & 12.7 & 12.8 & 12.8 & 12.6 & 12.8 & 13.1 & 13.1 & 13.2 \\
\hline Denmark & 11.0 & 11.1 & 11.0 & 10.8 & 11.1 & 10.9 & 11.1 & 11.2 & 11.5 & 11.3 & 11.5 & 11.4 & 11.3 & 11.8 & 11.5 & 11.8 & 11.8 & 11.8 & 12.0 & 12.0 & 12.1 & 12.4 & 12.5 \\
\hline Finland & 10.4 & 10.6 & 10.7 & 10.4 & 11.0 & 10.9 & 11.1 & 11.2 & 11.4 & 11.4 & 11.5 & 11.7 & 11.7 & 11.8 & 12.4 & 12.6 & 12.8 & 12.8 & 12.9 & 13.0 & 13.0 & 13.2 & 13.2 \\
\hline \multicolumn{24}{|c|}{90 years } \\
\hline Sweden & 3.9 & 4.0 & 4.0 & 3.9 & 4.2 & 4.1 & 4.1 & 4.1 & 4.2 & 4.1 & 4.2 & 4.1 & 4.0 & 4.2 & 4.3 & 4.3 & 4.3 & 4.2 & 4.2 & 4.4 & 4.3 & 4.4 & 4.3 \\
\hline Norway & 4.0 & 3.9 & 4.1 & 3.8 & 4.0 & 4.0 & 4.0 & 3.9 & 4.1 & 3.9 & 4.1 & 4.0 & 4.0 & 4.1 & 4.3 & 4.3 & 4.2 & 4.3 & 4.4 & 4.4 & 4.4 & 4.4 & 4.3 \\
\hline Iceland & 4.3 & 4.5 & 4.4 & 4.1 & 4.6 & 4.2 & 4.0 & 4.4 & 4.2 & 4.1 & 4.2 & 4.8 & 4.5 & 4.1 & 4.7 & 4.6 & 4.3 & 4.9 & 4.3 & 4.3 & 4.6 & 4.3 & 4.6 \\
\hline Denmark & 4.0 & 4.0 & 3.9 & 3.9 & 4.0 & 3.9 & 4.0 & 4.1 & 4.2 & 4.1 & 4.2 & 4.1 & 4.1 & 4.3 & 4.2 & 4.3 & 4.3 & 4.4 & 4.4 & 4.4 & 4.5 & 4.5 & 4.6 \\
\hline Finland & 3.7 & 3.9 & 3.8 & 3.6 & 3.8 & 3.9 & 3.7 & 3.7 & 3.8 & 3.8 & 3.8 & 3.9 & 3.7 & 3.9 & 4.2 & 4.2 & 4.3 & 4.2 & 4.3 & 4.4 & 4.3 & 4.3 & 4.3 \\
\hline \multicolumn{24}{|c|}{ Males } \\
\hline \multicolumn{24}{|c|}{75 years } \\
\hline Sweden & 8.9 & 9.0 & 9.2 & 9.1 & 9.5 & 9.4 & 9.5 & 9.6 & 9.6 & 9.7 & 9.9 & 10.0 & 10.0 & 10.1 & 10.4 & 10.3 & 10.5 & 10.6 & 10.7 & 10.8 & 10.9 & 11.0 & 11.0 \\
\hline Norway & 8.7 & 8.8 & 8.8 & 8.7 & 9.1 & 8.9 & 9.1 & 9.1 & 9.2 & 9.1 & 9.4 & 9.4 & 9.5 & 9.9 & 10.2 & 10.1 & 10.4 & 10.3 & 10.4 & 10.6 & 10.7 & 10.8 & 10.9 \\
\hline Iceland & 10.1 & 9.3 & 10.2 & 10.0 & 10.0 & 9.8 & 9.3 & 10.1 & 9.7 & 10.0 & 10.8 & 10.6 & 10.5 & 10.7 & 10.3 & 10.8 & 11.2 & 10.8 & 11.1 & 11.1 & 10.7 & 11.3 & 11.9 \\
\hline Denmark & 8.4 & 8.7 & 8.6 & 8.4 & 8.6 & 8.4 & 8.6 & 8.8 & 8.9 & 8.9 & 9.1 & 9.1 & 9.1 & 9.4 & 9.3 & 9.6 & 9.7 & 9.8 & 10.0 & 9.9 & 10.2 & 10.4 & 10.5 \\
\hline Finland & 8.2 & 8.4 & 8.3 & 8.3 & 8.8 & 8.7 & 8.7 & 8.9 & 8.9 & 9.0 & 9.1 & 9.3 & 9.3 & 9.6 & 9.9 & 10.1 & 10.1 & 10.2 & 10.5 & 10.5 & 10.5 & 10.7 & 10.7 \\
\hline \multicolumn{24}{|c|}{90 years } \\
\hline Sweden & 3.4 & 3.3 & 3.3 & 3.3 & 3.5 & 3.4 & 3.4 & 3.4 & 3.4 & 3.4 & 3.4 & 3.4 & 3.4 & 3.5 & 3.6 & 3.5 & 3.6 & 3.5 & 3.6 & 3.6 & 3.6 & 3.7 & 3.6 \\
\hline Norway & 3.3 & 3.5 & 3.3 & 3.1 & 3.4 & 3.2 & 3.4 & 3.3 & 3.5 & 3.3 & 3.4 & 3.4 & 3.3 & 3.4 & 3.6 & 3.6 & 3.6 & 3.5 & 3.5 & 3.7 & 3.6 & 3.8 & 3.6 \\
\hline Iceland & 4.3 & 3.8 & 4.0 & 4.2 & 4.0 & 4.0 & 3.7 & 3.9 & 3.8 & 3.5 & 3.7 & 3.7 & 4.2 & 3.7 & 3.6 & 3.7 & 3.5 & 3.6 & 4.0 & 3.6 & 3.4 & 3.9 & 4.0 \\
\hline Denmark & 3.4 & 3.5 & 3.3 & 3.3 & 3.4 & 3.2 & 3.3 & 3.3 & 3.5 & 3.4 & 3.5 & 3.5 & 3.4 & 3.5 & 3.4 & 3.6 & 3.6 & 3.6 & 3.5 & 3.5 & 3.7 & 3.7 & 3.8 \\
\hline Finland & 3.3 & 3.4 & 3.3 & 3.2 & 3.4 & 3.4 & 3.2 & 3.5 & 3.4 & 3.3 & 3.4 & 3.4 & 3.4 & 3.4 & 3.6 & 3.5 & 3.6 & 3.7 & 3.6 & 3.8 & 3.7 & 3.7 & 3.7 \\
\hline
\end{tabular}

